\title{
Development of an Aesthetic Agricultural Dust Mask
}

\author{
S. Jayakrishna*, S. S. Meena and G. S. Tiwari \\ Department of Farm Machinery and Power Engineering, College of Technology and \\ Engineering, Maharana Pratap University of Agriculture and Technology, Udaipur \\ (Rajasthan), India \\ *Corresponding author
}

K e y w o r d s
Agricultural dust,
Threshing
operation, Dust
concentration,
Symptoms,
Aesthetic dust
mask, Suitability
and Total score
Article Info
Accepted:
16 November 2020
Available Online:
10 December 2020

\section{A B S T R A C T}

Agricultural dust to which farmers carrying threshing operations were mostly exposed. Respiratory diseases associated with agricultural work were one of the first recognized occupational diseases of the lung. It is of three types, respirable dust; hazardous if deposited in gas exchange region of lungs, thoracic dust; hazardous if entered into airways of lungs and inhalable dust; hazardous if deposited in the head airway region and respiratory tree. The present study was conducted to develop an aesthetic dust protective mask, to determine the dust concentration in threshing operation at various distances from the thresher and its comparison with the standard exposure limits. An intervieweradministered survey questionnaire was designed for the investigation of symptoms in the farmers working with threshing operations. The prevalence of watery eyes, expectoration, and headache problems were higher in the farmers working with threshing operations. The dust concentration was measured at different distances (near, $2.5 \mathrm{~m}, 5.0 \mathrm{~m}$, and $7.5 \mathrm{~m}$ respectively) from the thresher. When operating under the open sun in day hours. The average dust concentration for total solid particulates at different locations very near, $2.5 \mathrm{~m}, 5.0 \mathrm{~m}$, and $7.5 \mathrm{~m}$ respectively from the thresher was recorded as $559.41 \mu \mathrm{g} / \mathrm{m}^{3}$, $1238.34 \mu \mathrm{g} / \mathrm{m}^{3}, 2613.91 \mu \mathrm{g} / \mathrm{m}^{3}$, and $1281.09 \mu \mathrm{g} / \mathrm{m}^{3}$. The dust concentration at the distance of $2.5 \mathrm{~m}$ varied from $350 \mu \mathrm{g} / \mathrm{m}^{3}$ to $5085 \mu \mathrm{g} / \mathrm{m}^{3}$ and it varied from 650 to $3500 \mu \mathrm{g} / \mathrm{m}^{3}$ at the distance of $7.5 \mathrm{~m}$ from the thresher. The average dust concentration values are below the standard exposure limit of $4000 \mu \mathrm{g} / \mathrm{m}^{3}$ as per ACGIH and OSHA. Aesthetically prepared dust masks were evaluated by threshing farmers against various performance parameters. The dust protectors were subjected to suitability tests of duration of a half-hour each on nine farmers. The towel type mask made with muslin aesthetic filter material was found most suitable and suited best for farmers and is followed by a hood mask made with muslin and mercerized cloth that equally performed well.

\section{Introduction}

In India, agriculture \& its allied sector is the backbone of the economy. It plays vital role in sustainable growth and development.
Agriculture is the prime source for livelihood of more than 60 per cent of India's population and wholly or significant portion of people depend on agriculture and allied activities for their livelihood. As Per the 2019 central 
agriculture statistics, India achieved record production of 281.37 million tons of food grains. According to statistics of world's agriculture, India is major producer for many fresh fruits and vegetables, spices, fibrous crops like cotton in the world. Indian agriculture is not only about food and nutrition, also producing different commercial crops like cotton, rubber, coffee and sugar cane are being produced to meet industrial needs. However it contributes to 16 per cent of national GDP at current prices in 20182019 (Anonymous, 2019).

As per land use statistics 2014- 15, total geographical area of the India is 328.73 million hectares, of which 140.13 million hectares is reported as net sown area and 198.36 million hectares is gross cropped area. As per $4^{\text {th }}$ advance estimates for $2015-16$. The total food grains production in the country is estimated at 252.22 million tones which is marginally higher by 0.20 million tones than the previous year's food grain production of 252.02 million tones and pulses production is estimated at 16.47 tones is lower by 0.68 million tones than their production during the previous year (Agriglance, 2018).

A large part of agriculture continues to be rain fed and primarily dependent on monsoons. As per 2014-15 statistics India achieved a record level of $53.05 \%$ irrigation for food grains, introduced high efficient water usage drip irrigation systems through various government schemes. The state of Punjab is leading in India, achieved $99 \%$ of irrigation for food grains. As India is world's second largest country in terms of population with 1.3 billion (Anonymous, 2015). The progressive fragmentation of landholdings, reduction in natural resources and effects of climate change are further escalated pressure on land \& water. In the country around $85 \%$ of agricultural land holdings are small and marginal. Medium farm holdings are frequently getting converted into small and marginal (Fig. 1-10 and Table 1-4).

\section{Agricultural dust}

India is home to a wide variety of climatic regions, ranging from tropical in the south to temperate (Anonymous). Most of the agricultural operations in the country are still being performed by manual labor accounts for $49 \%$ (FICCI, 2012). The farmers has to work under the open sun in the hot environment thereby chances of heat stress likely heatstroke, heat exhaustion and skin problems are very high. Most of farmers work under a very risky $\&$ hazardous health condition that needs to be reduced. Most of the research on agricultural respiratory disease has appropriately focused on disorders caused by organic dust exposures (Schenker, 2000).

The dust pollution and working under open sun, leads farmers to suffer from prolonged health problems. The survey on operators (Selçuk ARSLAN 2010) showed that there were health complaints in terms of coughing, phlegm, chest tightness, and breathlessness at varying levels. Smoking habit increased the health complaints of the agricultural workers. As we know that the agricultural activities are Energy-intensive operations, and a farmer works at elevated heart rate, and increased respiration rate, which increases further inhaling of more dust particulates at the workplace (Christensen et al., 1992).

Different sizes of straw, straw-particulates and straw dust are generated during the threshing operations and processing. Dust thus generated should create an adverse working environment. Threshing is an important labor-intensive agricultural operation. A labour needs to perform intense work continuously which results in an elevated heart rate (W.H.M morris) and further inhaling of more dust particles so Use 
of PPEs (Personal Protective Equipment) is one of the key components of workplace health and safety practices for ensuring overall health and safety of workers (Apreko et al., 2015).

The following are the types of dust and its particle sizes.

\section{Inhalable particulate fraction}

Inhalable dust enters the body but it is trapped in the nose, throat and upper respiratory tract. The size of this dust is below $100 \mu \mathrm{m}$ and above $10 \mu \mathrm{m}$. According to WHO, the inhalable exposure limit is $10 \mathrm{mg} / \mathrm{m}^{3}$.

\section{Thoracic particulate fraction}

Thoracic dust is defined as those materials that are hazardous when deposited anywhere within the lung airways and the gas exchange region. The size of this dust is between 5-10 $\mu \mathrm{m}$. According to $\mathrm{WHO}$, the thoracic dust exposure limit is $3-5 \mathrm{mg} / \mathrm{m}^{3}$ which can reach the lower respiratory system.

\section{Respirable particulate fraction}

Respirable dust is defined as that fraction of the dust reaching the alveolar region of the lungs. According to $\mathrm{WHO}$, the size of this dust is about $0.2-5 \mu \mathrm{m}$.

\section{Justification}

The present study will be conducted to design aesthetic dust preventing mask favorable to protect agricultural workers from exposure to dust during threshing operations. Respiratory diseases associated with agricultural work were one of the first recognized occupational diseases of the lung. It has long been appreciated that exposures to organic dust are potentially harmful to the respiratory tract. (Simpson, J. C. G., et al.1999) Major research is needed to characterize the nature, safety limits of agricultural dust exposure while threshing operations carried under the open sun environment. The occupationally related lung diseases are most likely due to the deposition of dust in the lungs and are influenced by the type of dust, the period of exposure, the concentration and size of airborne dust in the breathing zone (Kim, Kun-Il, et al., 2001).

Dust is generated while processing rice, wheat, oilseeds, and tea. Dust emission depends on raw materials, processes involved, and equipment. Workers during different threshing operations are thus exposed to varying amounts of dust. Dust inhalation is a major occupational health hazard on respiratory systems, skin, and eyes to workers. Dust exposure causes inflammatory reactions of the pulmonary tissues, and asthma-related diseases from rice husk (Singh et al., 1988).

In most cases, farmers do not show interest to carry dust masks at all working conditions except in few operations involving heavy dust exposure. Also, farmers are more inclined to use single layer cotton cloth to protect from dust due to lack of patience while under a heavy workload and due to lack of knowledge on hazardous health effects in long durations due to medium level dust exposure. To overcome these problems it is proposed to develop an aesthetic dust mask that can be an integral part of the embodiments used while working. To protect the worker from dust exposure that significantly affects the health and working efficiency of farmers.

\section{Materials and Methods}

This chapter deals with the materials used and methods followed in conducting the research work. A detailed survey to find adverse effects of dust on health condition of farmers working in threshing operations is being conducted in Udaipur region with suitable 
assessment form to find out the health conditions and pro longed health hazards they are facing due to dust in threshing operations carried out in open farms.

The farmers who are frequently working in threshing operations are being chosen and visited with aim of assessing their health condition. The survey is only conducted on male farmers having agriculture as only source of income.

It is designed such that an interviewer ask the questionnaire regarding health condition and investigates the symptoms of health hazards such as cough, bleeding of nose, headache, secretion etc. the additional questions relating to age, smoking habit, use of personal protective device by workers and locations of major dust prone areas near the area of threshing site in views of farmers working on it also included. Further details of availability of dust protective devices, their cost and protective devices prepared by their own are being investigated.

The total dust concentration in air at different locations (i.e. near thresher, $2.5 \mathrm{~m}, 5 \mathrm{~m}$ and $7.5 \mathrm{~m}$ ) from thresher are recorded by using (PALAS FIDAS Frog) dust monitor, Temperature and relative humidity also being measured with same device. It is particularly helpful to suggest farmers nearest distance and different locations from thresher at which dust protectors are totally essential.

An Aesthetic dust protector having filter materials integrated in normal routine usage devices by farmers such as towels and head gears should be developed. It encourages the farmers to use dust protective devices also saving their time of carrying dust protectors and cost specially invested on dust protectors. All the different dust masks prepared should be distributed among the farmers and subjected to suitability test for a half- hour at each farmer. Thus total acceptability score for different Aesthetic dust masks was obtained as per farmer's response. Based on the results aesthetically more acceptable dust mask is being advised for farmers working with threshing operations.

\section{Plan of work}

The main objectives on which the conduct of research \& whole project work are based as follows.

\section{Objective I}

Subjective assessment of dust exposure level during threshing Operation \& health hazards faced by farmers.

\section{Objective II}

To develop an aesthetic dust mask \& measurement of dust, Concentration at, Threshing site.

\section{Objective III}

Evaluation of developed dust

Mask for its suitability and Acceptability of farmers.

\section{Objective I}

Subjective assessment of dust exposure level during threshing Operation \& health hazards faced by farmers.

Under this objective, a suitable assessment form is being prepared to easily identify \& allow farmers to select the conditions they are working, safety measures being followed, their health conditions and health problems they are suffering from due to dust exposure and adverse conditions at worksite. The farmers undertaking threshing operations in open fields will be chosen, visited with the 
aim of assessing the safety measures being followed by farmers along with the health conditions during threshing operations.

\section{Assessment form}

The Assessment form is divided into five sections. The first section consists of personal information of the farmer which includes his name, age, sex, level of education, place /village and smoking habits. The second section asks the workers to select the protective devices being used by them to avoid respiratory, hearing and skin problems. The protective gear against respiratory problems includes a nuisance dust mask and damp towel.

The protective gear against hearing problems are ear muffs and earplugs. The protective gear against skin problems includes impervious gloves and cotton gloves. The workers can select whether they are using any of the mentioned equipment in each category or not. The third section assesses the experience of workers. The fourth section deals with information regarding major dust prone area at the threshing site in views experienced farmers working with threshing operations. And the fifth section deals with any health problems the workers might be suffering from as a consequence of intensive workload during threshing.

Farmers can select from a list of health problems which include cough, chest tightness, irritation or dryness of throat, asthma, secretion, dryness or bleeding of nose, headache and poor eyesight. To describe the level of health hazard they simple can choose the options of strongly agreed, agreed, undecided, disagreed and strongly disagreed. This subjective assessment also includes information about worker's acceptability and interest in using various protective equipment during threshing operations.
A detailed survey is conducted on farmers frequently working with threshing operations.

\section{Sources of dust emission in thresher}

\section{Crop feeding chute}

The crop is fed into thresher by means feeding chute located at one end of the threshing drum. Threshing labour repeatedly feeds the dried crop into threshing drum either by pressing crop against high-speed rotating cylinder of by means of gravitational flow. The impact of sun dried crop by high speed threshing drum generates the dust inside the thresher. Hence farmer feeding the crop at thresher is partially exposed to threshing dust.

\section{Threshing unit}

Threshing interface is the fundamental theory of techniques and equipment. It consists of two contact surfaces of grain ear and threshing component are major factors of threshing. (Fu Jun et al, 2018). Impact of crop against high speed threshing drum is commonly used efficient method for removal of grain or pods from chaff but this process also generates high amounts of dust inside threshing unit.

\section{Aspirator or blower}

After threshing unit carries out threshing, the cleaning and separation of straw from grains required. Aspirator fan is generally installed on main shaft, blows the high speed current of air stream than lighter material chaff and other portion of plant are thrown away from outlet.

\section{Straw outlet}

After the all grain pods are separated from the chaff. The remaining straw is thrown away from the straw outlet that contains lighter 
particles of straw dust. The straw outlet is one of the major sources of dust in agriculture.

\section{Dust concentration level at threshing operation}

\section{Independent variables}

\section{Location selected for readings}

They are very near the thresher, $2.5 \mathrm{~m}, 5 \mathrm{~m}$, and $7.5 \mathrm{~m}$ respectively from thresher.

\section{Dependent variables}

\section{Concentration of dust particles (mg/m3)}

For accuracy in determining the concentration of dust particles $(\mathrm{mg} / \mathrm{m} 3)$ measurements are done in two directions perpendicular to each other at selected distances from thresher.

\section{Comparison with standard exposure limits}

Measured level of dust concentrations (mg/m3) were compared with mean standard exposure limits given by ACGIH (American Conference of Governmental Industrial Hygienists) and OSHA's (Occupational Safety and Health Administration) PEL (Permissible Exposure limits).

To find the radius of circle with in which personal protective devices are essential to protect from dust (or) to find the safest distance to be maintained to be maintained from thresher to work without personal protective devices. The standard exposure limits are given in below table.

Standard exposure limits (OSHA, 2018)

\begin{tabular}{|c|c|c|}
\hline Safety measurement & $\begin{array}{c}\text { ACGIH } \\
\text { (mg/m3) }\end{array}$ & $\begin{array}{c}\text { OSHA } \\
\text { (mg/m3) }\end{array}$ \\
\hline $\begin{array}{c}\text { Threshold limit value } \\
\text { (TLV) }\end{array}$ & 4 & 4 \\
\hline $\begin{array}{c}\text { Permissible exposure limit } \\
\text { (PEL) }\end{array}$ & 10 & 10 \\
\hline
\end{tabular}

\section{Threshold limit value (TLV)}

It is air borne concentration of toxic substance to which a worker can repeatedly be exposed day after day for working lifetime without any adverse effects. Strictly Threshold limit value (TLV) is reserved term of (ACGIH) American Conference of Governmental Industrial Hygienists. ACGIH TLV for grain dust is $4 \mathrm{mg} / \mathrm{m} 3$ as an 8 hour time weighted average.

\section{Permissible exposure limit (PEL)}

The permissible exposure limit is legal limit for exposure of farmers to a chemical substance like threshing dust. Permissible exposure limits are established by the (OSHA) Occupational Safety and health Administration. OSHA PEL for grain dust is $10 \mathrm{mg} / \mathrm{m} 3$ as an 8 hour time weighed Average.

Objective II: To develop an aesthetic Agricultural dust mask \& Measurement of dust Concentration at threshing site.

\section{Anthropometric data of male agricultural farmers}

Sampling Plan: The populations were sampled by age and gender. A stratified sampling plan will be used with equal sample sizes in each cell. Each cell was statistically independent. The single age strata is consisted (28-50years), gender strata (male).

Dimensions Measured: Dimensions will be selected to maximize the information that could be obtained from each subject for design of aesthetic agricultural dust mask and its testing.

Most dimensions will be measured on the face, including minimum frontal breadth and nose breadth, head length and breadth measurements. 
Anthropometric data: Anthropometric data of male agricultural farmers of 28 or above age (Sanwal Singh Meena, 2019) is as follows.

Selection of materials for the designing an aesthetic dust mask

Type of pattern/ design to the dust mask

Long towel type

Beak mask type

Hood mask type

Aesthetic cloth materials

Muslin cloth

Mercerized cloth

Aesthetic parameters considered for selection of cloth materials

Colour

Texture

Softness

\section{Filter material}

Cotton layer gives high filtration efficiency with possibly less breathing resistance and is more absorbent to dust particles. Cotton gives comfortable spongy touch so that it should not be very tight to wear mask by farm workers. Raw Cotton layer of $1.5 \mathrm{~mm}$ thickness is used for filter material which is sandwiched between aesthetic cloth materials.

Filter material of mask will be made in different colours by using aesthetic clothes as follows.

\section{Aesthetic cloth materials}

\begin{tabular}{|c|c|c|c|}
\hline $\begin{array}{c}\text { Aesthetic cloth } \\
\text { materials }\end{array}$ & \multicolumn{3}{|c|}{ Clothes of different colours } \\
\cline { 2 - 4 } & C1 & C2 & C3 \\
\hline $\begin{array}{c}\text { Muslin cloth } \\
\text { (M1) }\end{array}$ & M1C1 & M1C2 & M1C3 \\
\hline $\begin{array}{c}\text { Mercerized cloth } \\
\text { (M2) }\end{array}$ & M2C1 & M2C2 & M2C3 \\
\hline
\end{tabular}

The material of mask thus prepared is attached to five different designs/patterns of masks i.e. Long towel type, Full face cover, Headgear type, Hood mask and Scarf mask to make it acceptable by farmer at desired working environment.

Farmers performing threshing operation with developed long towel type of dust mask

\section{Instrumentation}

\section{Palas Fidas ${ }^{\circledR}$ Frog fine dust monitor}

It measures simultaneously the environmentally relevant mass fractions PM1, PM2.5, PM4, PM10, TSP as well as the particle number and the particle size distribution within the particle size range of $0.18-100 \mu \mathrm{m}$. By providing fine dust values with high time resolution, the operator receives comprehensive information for evaluation and assessment of the fine dust pollution for the investigated application. The very compact and light design as a portable hand-held monitor with either battery or mains power operation as well as the operation time of up to 8 hours per battery charge, allow for a flexible application of the Fidas ${ }^{\circledR}$ Frog at any measurement sites.

Objective III: Evaluation of developed dust mask for its suitability and acceptability of farmers working with threshing operations.

Evaluation of developed aesthetic dust mask

Type of variables

Independent variables

Different types of Aesthetic dust masks

Long towel type 
Beak mask type

Hood mask type

\section{Dependant variables}

\section{Performance parameters}

Communication ease

Breathing ease

Skin comfort

In mask temperature

Face and head fit

Weight convience

Appearance

Ease of wearing

Overall comfortness

The form mainly consists of two sections. The first section is to collect personal information of farmer and second section consists of performance indicators. Each of performance indicators are further classified as low, medium and high respectively, that farmer can choose performance capacity and discomfort level of dust mask being used by him. Thus total acceptability score was obtained for all aesthetic dust masks and most suitable one is suggested for farmers frequently working with threshing operations.

\section{Results and Discussion}

The present chapter deals with results and discussion part that obtained by investigation as per objectives of the research work. i.e. the subjective assessment of dust exposure level in threshing operation and safest distance from thresher at which dust exposure levels are below standard limits and to evaluation of aesthetically developed agricultural dust mask for its suitability and acceptability of farmers working with threshing operations.

Results of the study are discussed as follows

1. Details of threshing operations investigated 2. Environmental parameters
3. Subjective assessment of dust exposure \& health hazards faced by farmers.

4. Dust concentration level at threshing operation.

5. Suitability of aesthetic agricultural dust mask

\section{Details of threshing operations investigated}

The detailed study is conducted on farmers frequently working with threshing operation at CTAE farm, Udaipur. On investigation it is found that most of farmers are using single layer towel as personal protective devices to protect from threshing dust. Threshing operation for soya bean crop is being carried out by a total of 9 farmers for 7.5 hours in a day. Production capacity of $45 \mathrm{bags}$ of soya bean per day is observed. Net weight of each bag is approximately $40 \mathrm{~kg}$. The dust concentration $\left(\mathrm{mg} / \mathrm{m}^{3}\right)$ at different distances from the thresher was noted for further study to identify safe distance from thresher where the dust concentration is below limited value.

While working with threshing operations farmers are using full shirt to protect hands from dust and especially not using any coverings on hands and heads during the threshing operation. Also they are using single layer towel to cover face and nose instead of using a specific masks. Understandably it shows the lack of awareness in farmers on adverse effects caused due to excessive exposure to threshing dust for a long period of time.

Farmers taking a rest of 10 minutes for every one hour to prevent over dehydration under open sun, excessive heat trap in clothes and to drink water are being observed. Also it is said that proper rest cycle improves the working efficiency of farmers working at elevated heart rates. 
Table.1 Allocation of farmer's data as per the reported symptoms due to threshing dust

\begin{tabular}{|c|c|c|c|c|c|c|}
\hline Sr.no & Symptoms & $\begin{array}{c}\text { Strongly } \\
\text { agreed }\end{array}$ & Agreed & Undecided & Disagreed & $\begin{array}{l}\text { Strongly } \\
\text { disagreed }\end{array}$ \\
\hline 1 & Cough & $1(11.1 \%)$ & $4(44 \%)$ & $2(22 \%)$ & $2(22 \%)$ & - \\
\hline 2 & Chest tightness & $4(44 \%)$ & $3(33.3 \%)$ & $2(22 \%)$ & - & - \\
\hline 3 & Dryness of the throat & $2(22.2 \%)$ & $4(44 \%)$ & $1(11.1 \%)$ & $2(22 \%)$ & $1(11.1 \%)$ \\
\hline 4 & Secretion & $1(11.1 \%)$ & $1(11.1 \%)$ & $4(44 \%)$ & $1(11.1 \%)$ & $2(22 \%)$ \\
\hline 5 & Bleeding of the nose & - & $1(11.1 \%)$ & $2(22 \%)$ & $3(33.3 \%)$ & $2(22 \%)$ \\
\hline 6 & Headache & $2(22.2 \%)$ & $5(55.6 \%)$ & $2(11.1 \%)$ & - & - \\
\hline 7 & Expectoration & $4(44 \%)$ & $3(33.3 \%)$ & $1(11.1 \%)$ & $1(11.1 \%)$ & - \\
\hline 8 & $\begin{array}{l}\text { Eye sight and watery } \\
\text { eyes }\end{array}$ & $5(55.6 \%)$ & $4(44 \%)$ & - & - & - \\
\hline 9 & Skin rash & $1(11.1 \%)$ & $1(11.1 \%)$ & $3(33.3 \%)$ & $4(44 \%)$ & - \\
\hline
\end{tabular}

Table.2 Average dust concentration at different distances from thresher (near, 2.5, 5.0, \&7.5m)

\begin{tabular}{|c|c|}
\hline \multicolumn{2}{|c|}{ Location 1: Near to thresher } \\
\hline Dust particulates & Dust concentration $\left(\mu \mathrm{g} / \mathrm{m}^{3}\right)$ \\
\hline PM 1 & $: 129.87$ \\
\hline PM 2.5 & $: 165.49$ \\
\hline PM 4 & : 221.83 \\
\hline PM 10 & $: 353.78$ \\
\hline PM tot. & $: 559.41$ \\
\hline \multicolumn{2}{|c|}{ Location $2: 2.5$ meters from thresher } \\
\hline Dust particulates & Dust concentration $\left(\mu \mathrm{g} / \mathrm{m}^{3}\right)$ \\
\hline PM 1 & $: 95.91$ \\
\hline PM 2.5 & $: 160.23$ \\
\hline PM 4 & : 229.98 \\
\hline PM 10 & $: 579.31$ \\
\hline PM tot. & $: 1238.34$ \\
\hline \multicolumn{2}{|c|}{ Location $3: 5.0$ meters from thresher } \\
\hline Dust particulates & Dust concentration $\left(\mu \mathrm{g} / \mathrm{m}^{3}\right)$ \\
\hline PM 1 & $: 105.67$ \\
\hline PM 2.5 & : 234.61 \\
\hline PM 4 & $: 367.77$ \\
\hline PM 10 & $: 1128.15$ \\
\hline PM tot. & $: 2613.91$ \\
\hline \multicolumn{2}{|c|}{ Location $4: 7.5$ meters from thresher } \\
\hline Dust particulates & Dust concentration $\left(\mu \mathrm{g} / \mathrm{m}^{3}\right)$ \\
\hline PM 1 & $: 87.84$ \\
\hline PM 2.5 & $: 155.25$ \\
\hline PM 4 & : 224.01 \\
\hline PM 10 & $: 615.64$ \\
\hline PM tot. & $: 1281.09$ \\
\hline
\end{tabular}


Table.3 Frequency of farmers providing the feedback for muslin cloth masks based on performance indicators

\begin{tabular}{|c|c|c|c|c|c|c|c|c|c|c|}
\hline \multirow{2}{*}{$\begin{array}{l}\text { Performance } \\
\text { indicator }\end{array}$} & \multirow[t]{2}{*}{ level } & \multicolumn{9}{|c|}{ Aesthetic dust mask } \\
\hline & & $\begin{array}{c}\text { M1C1 } \\
\text { P1 }\end{array}$ & $\begin{array}{l}\text { M1C1 } \\
\text { P2 }\end{array}$ & $\underset{\text { P3 }}{\text { M1C1 }}$ & $\begin{array}{c}\text { M1C2 } \\
\text { P1 }\end{array}$ & $\begin{array}{c}\text { M1C2 } \\
\text { P2 }\end{array}$ & $\begin{array}{c}\text { M1C2 } \\
\text { P3 }\end{array}$ & $\begin{array}{c}\text { M1C3 } \\
\text { P1 }\end{array}$ & $\begin{array}{c}\text { M1C3 } \\
\text { P2 }\end{array}$ & $\begin{array}{c}\text { M1C3 } \\
\text { P3 }\end{array}$ \\
\hline \multirow{3}{*}{$\begin{array}{l}\text { Communi-cation } \\
\text { ease }\end{array}$} & Low & 1 & 2 & 1 & 1 & 2 & 1 & 1 & 2 & 1 \\
\hline & Medium & 5 & 5 & 4 & 5 & 5 & 4 & 5 & 5 & 4 \\
\hline & High & 3 & 2 & 4 & 3 & 2 & 4 & 3 & 2 & 4 \\
\hline \multirow{3}{*}{$\begin{array}{l}\text { Breathing } \\
\text { Ease }\end{array}$} & Low & 1 & 1 & 1 & 1 & 1 & 1 & 1 & 1 & 1 \\
\hline & Medium & 4 & 6 & 5 & 4 & 6 & 5 & 4 & 6 & 5 \\
\hline & High & 4 & 2 & 3 & 4 & 2 & 3 & 4 & 2 & 3 \\
\hline \multirow{3}{*}{$\begin{array}{l}\text { In mask } \\
\text { temperature }\end{array}$} & Low & 1 & 2 & 1 & 1 & 2 & 1 & 1 & 2 & 1 \\
\hline & Medium & 7 & 6 & 6 & 7 & 6 & 6 & 7 & 6 & 6 \\
\hline & High & 1 & 1 & 2 & 1 & $\mathbf{1}$ & 2 & 1 & 1 & 2 \\
\hline \multirow{3}{*}{ Weight convience } & Low & $\mathbf{0}$ & 2 & 1 & $\mathbf{0}$ & 2 & 1 & $\mathbf{0}$ & 2 & 1 \\
\hline & Medium & 5 & 5 & 6 & 5 & 5 & 6 & 5 & 5 & 6 \\
\hline & High & 4 & 2 & 2 & 4 & 2 & 2 & 4 & 2 & 2 \\
\hline \multirow{3}{*}{ Appearance } & Low & 5 & 3 & 2 & 1 & 4 & 1 & $\mathbf{0}$ & 0 & 0 \\
\hline & Medium & 3 & 6 & 5 & 6 & 5 & 4 & 4 & 7 & 6 \\
\hline & High & 1 & 0 & 2 & 2 & O & 4 & 5 & 2 & 3 \\
\hline \multirow{2}{*}{ Skin comfort } & Good & 6 & 4 & 7 & 6 & 4 & 7 & 6 & 4 & 7 \\
\hline & Poor & 3 & 5 & 2 & 3 & 5 & 2 & 3 & 5 & 2 \\
\hline \multirow{2}{*}{$\begin{array}{l}\text { Ease of } \\
\text { Wearing }\end{array}$} & Good & 6 & 7 & 4 & 6 & 7 & 4 & 6 & 7 & 4 \\
\hline & Poor & 3 & 2 & 5 & 3 & 2 & 5 & 3 & 2 & 5 \\
\hline \multirow{2}{*}{$\begin{array}{l}\text { Overall } \\
\text { discomfort }\end{array}$} & Good & 6 & 4 & 7 & 6 & 4 & 7 & 6 & 4 & 7 \\
\hline & Poor & 3 & 5 & 2 & 3 & 5 & 2 & 3 & 5 & 2 \\
\hline
\end{tabular}

Table.4 Frequency of farmers providing the feedback for mercerized cloth masks based on performance indicators

\begin{tabular}{|c|c|c|c|c|c|c|c|c|c|c|}
\hline \multirow{2}{*}{$\begin{array}{l}\text { Performance } \\
\text { indicator }\end{array}$} & \multirow[t]{2}{*}{ level } & \multicolumn{9}{|c|}{ Aesthetic dust mask } \\
\hline & & $\begin{array}{c}\text { M2C1 } \\
\text { P1 }\end{array}$ & $\begin{array}{l}\text { M2C1 } \\
\text { P2 }\end{array}$ & $\begin{array}{c}\text { M2C1 } \\
\text { P3 }\end{array}$ & $\begin{array}{c}\text { M2C2 } \\
\text { P1 }\end{array}$ & $\begin{array}{c}\text { M2C2 } \\
\text { P2 }\end{array}$ & $\begin{array}{c}\text { M2C2 } \\
\text { P3 }\end{array}$ & $\begin{array}{c}\text { M2C3 } \\
\text { P1 }\end{array}$ & $\begin{array}{c}\text { M2C3 } \\
\text { P2 }\end{array}$ & $\begin{array}{c}\text { M2C3 } \\
\text { P3 }\end{array}$ \\
\hline \multirow{3}{*}{$\begin{array}{l}\text { Communi-cation } \\
\text { ease }\end{array}$} & Low & 2 & 2 & 1 & 2 & 2 & 1 & 2 & 2 & 1 \\
\hline & Medium & 6 & 6 & 6 & 6 & 6 & 6 & 6 & 6 & 6 \\
\hline & High & 1 & 1 & 2 & 1 & 1 & 2 & 1 & 1 & 2 \\
\hline \multirow{3}{*}{$\begin{array}{l}\text { Breathing } \\
\text { Ease }\end{array}$} & Low & 2 & 3 & 2 & 2 & 3 & 2 & 2 & 3 & 2 \\
\hline & Medium & 5 & 6 & 6 & 5 & 6 & 6 & 5 & 6 & 6 \\
\hline & High & 2 & 0 & 1 & 2 & 0 & 1 & 2 & 0 & 1 \\
\hline \multirow{3}{*}{$\begin{array}{l}\text { In mask } \\
\text { temperature }\end{array}$} & Low & 1 & 1 & 1 & 1 & 1 & 1 & 1 & 1 & 1 \\
\hline & Medium & 6 & 7 & 6 & 6 & 7 & 6 & 6 & 7 & 6 \\
\hline & High & 2 & 1 & 2 & 2 & 1 & 2 & 2 & 1 & 2 \\
\hline \multirow[t]{3}{*}{ Weight convience } & Low & 2 & 1 & 0 & 2 & 1 & 0 & 2 & 1 & 0 \\
\hline & Medium & 5 & 6 & 8 & 5 & 6 & 8 & 5 & 6 & 8 \\
\hline & High & 2 & 2 & 1 & 2 & 2 & 1 & 2 & 2 & 1 \\
\hline \multirow[t]{3}{*}{ Appearance } & Low & 5 & 3 & 2 & 1 & 4 & 1 & 0 & 1 & 0 \\
\hline & Medium & 2 & 5 & 4 & 5 & 4 & 3 & 4 & 6 & 6 \\
\hline & High & 2 & 1 & 3 & 3 & 1 & 5 & 5 & 2 & 3 \\
\hline \multirow[t]{2}{*}{ Skin comfort } & good & 7 & 6 & 8 & 7 & 6 & 8 & 7 & 6 & 8 \\
\hline & poor & 2 & 3 & 1 & 2 & 3 & 1 & 2 & 3 & 1 \\
\hline \multirow{2}{*}{$\begin{array}{l}\text { Ease of } \\
\text { wearing }\end{array}$} & Good & 7 & 8 & 6 & 7 & 8 & 6 & 7 & 8 & 6 \\
\hline & poor & 2 & 1 & 3 & 2 & 1 & 3 & 2 & 1 & 3 \\
\hline \multirow{2}{*}{$\begin{array}{l}\text { Overall } \\
\text { discomfort }\end{array}$} & good & 7 & 4 & 7 & 7 & 4 & 7 & 7 & 4 & 7 \\
\hline & poor & 2 & 5 & 2 & 2 & 5 & 2 & 2 & 5 & 2 \\
\hline
\end{tabular}


Fig.1 Deposition of dust particles of various size $(\mu \mathrm{m})$ in the respiratory tract

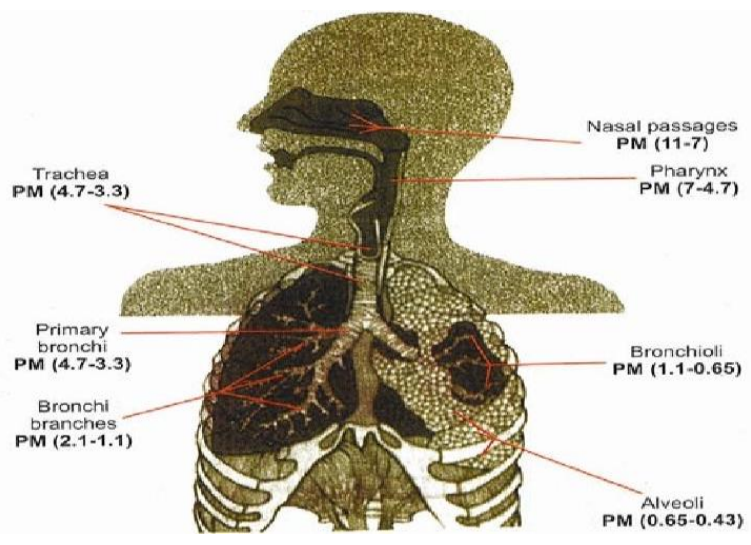

Fig.2 Farmer using towel to protect from dust

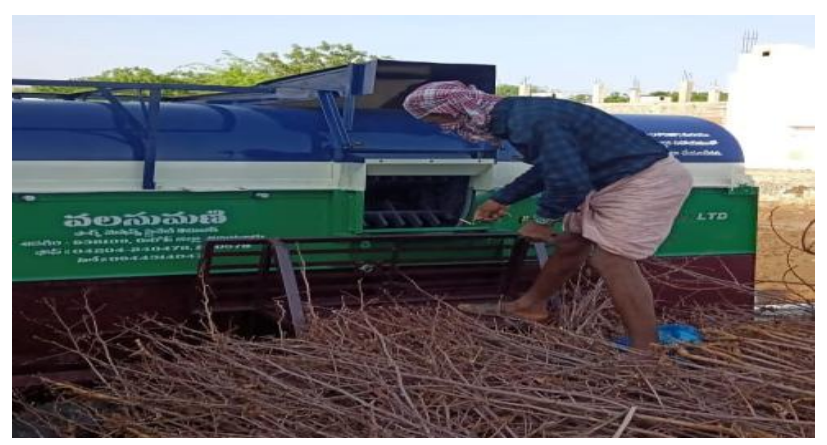

Fig.3 Farmers working without PPE devices

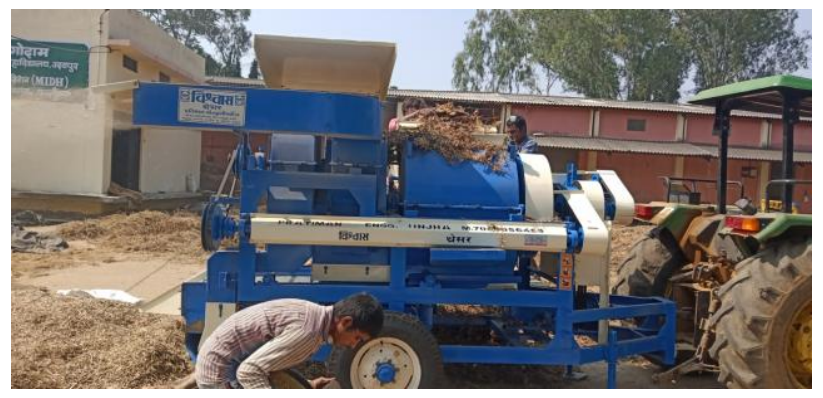

Fig.4 Conduct of survey on farmers at threshing site

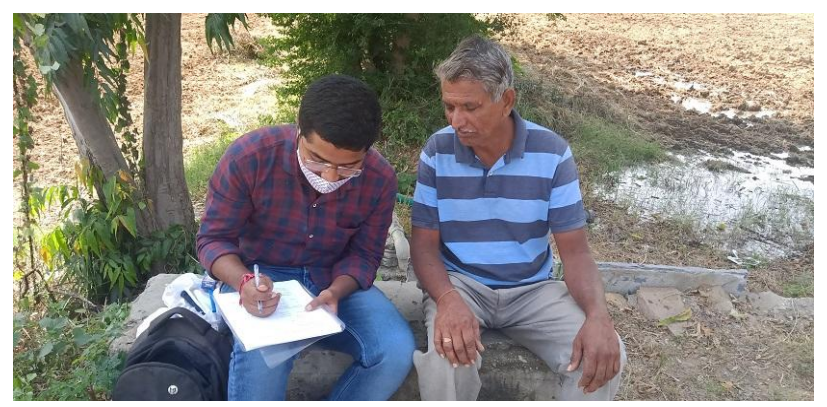


Fig.5 Measuring dust concentration near the thresher

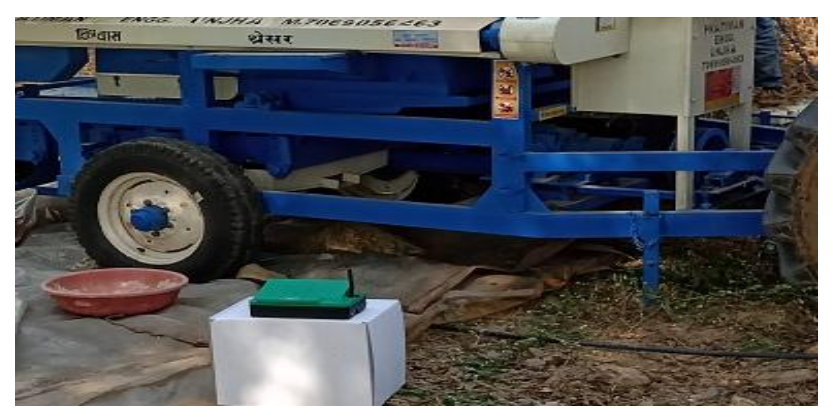

Fig.6 Measuring dust concentration at $2.5 \mathrm{~m}$ away from thresher

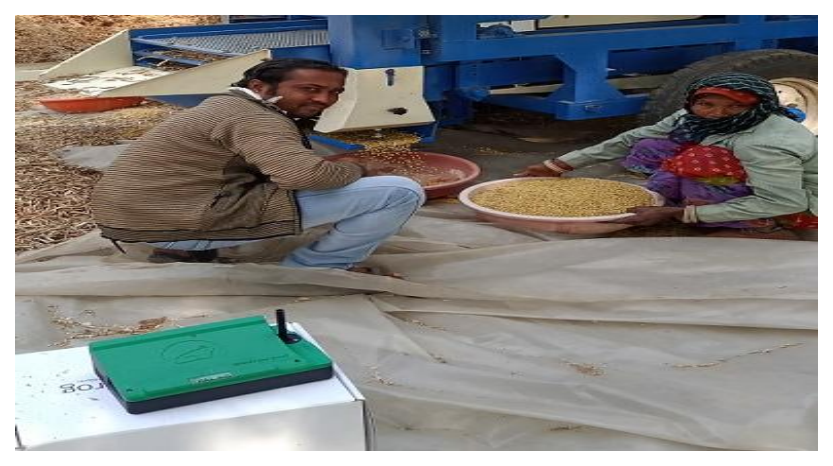

Fig.7 Measuring dust concentration at $7.5 \mathrm{~m}$ away from thresher

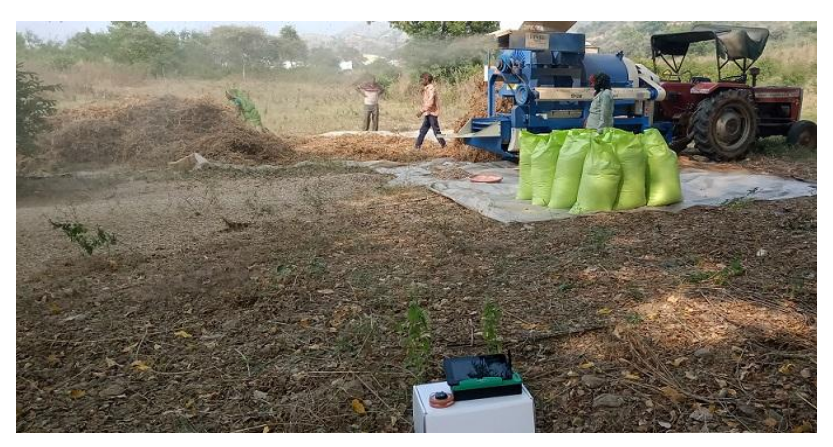

Fig.8

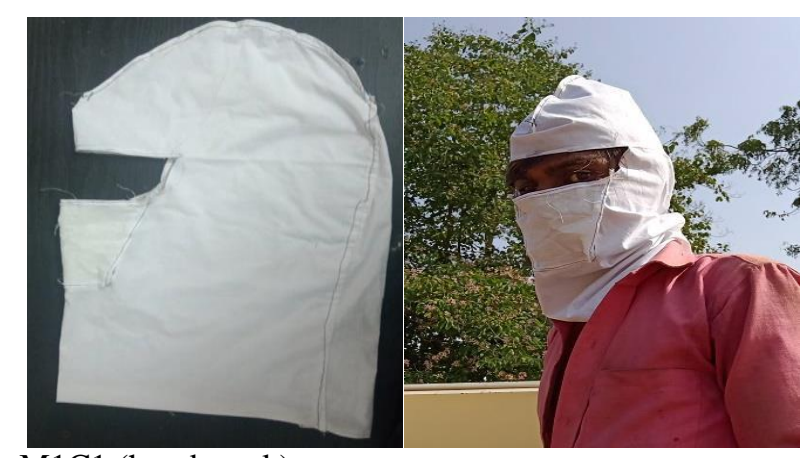

M1C1 (hood mask) 


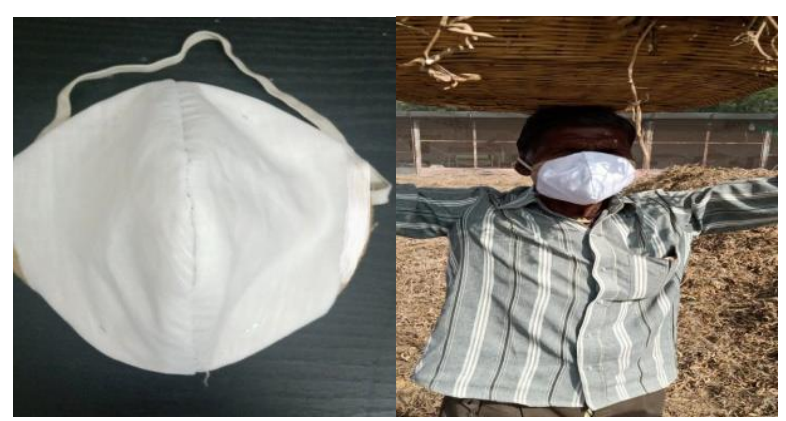

M1C1 (beck mask)
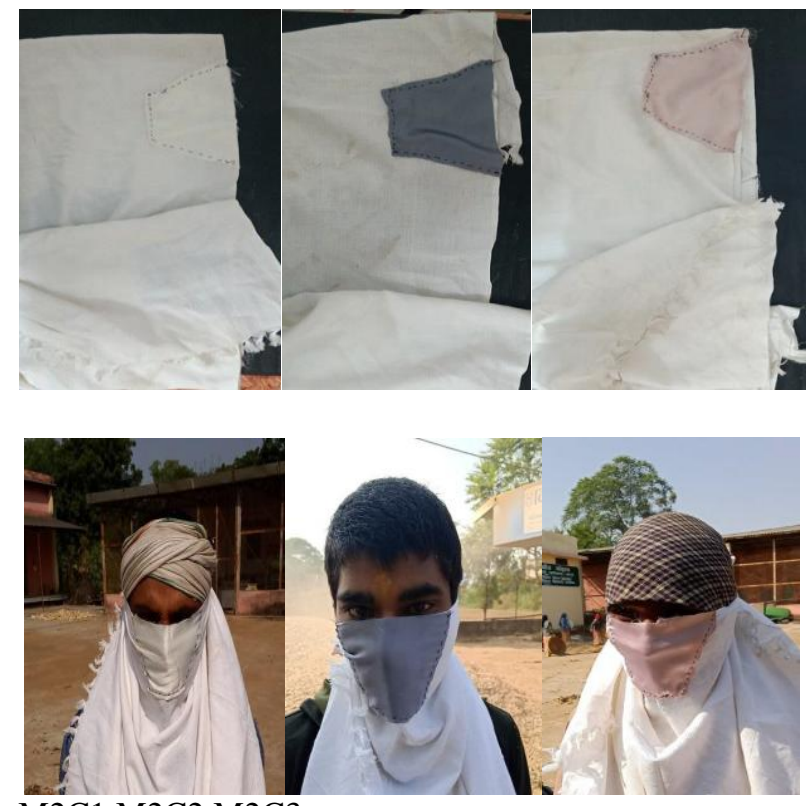

$\mathrm{M} 2 \mathrm{C} 1 \mathrm{M} 2 \mathrm{C} 2 \mathrm{M} 2 \mathrm{C} 3$

(Long towel type mask)

Fig.9

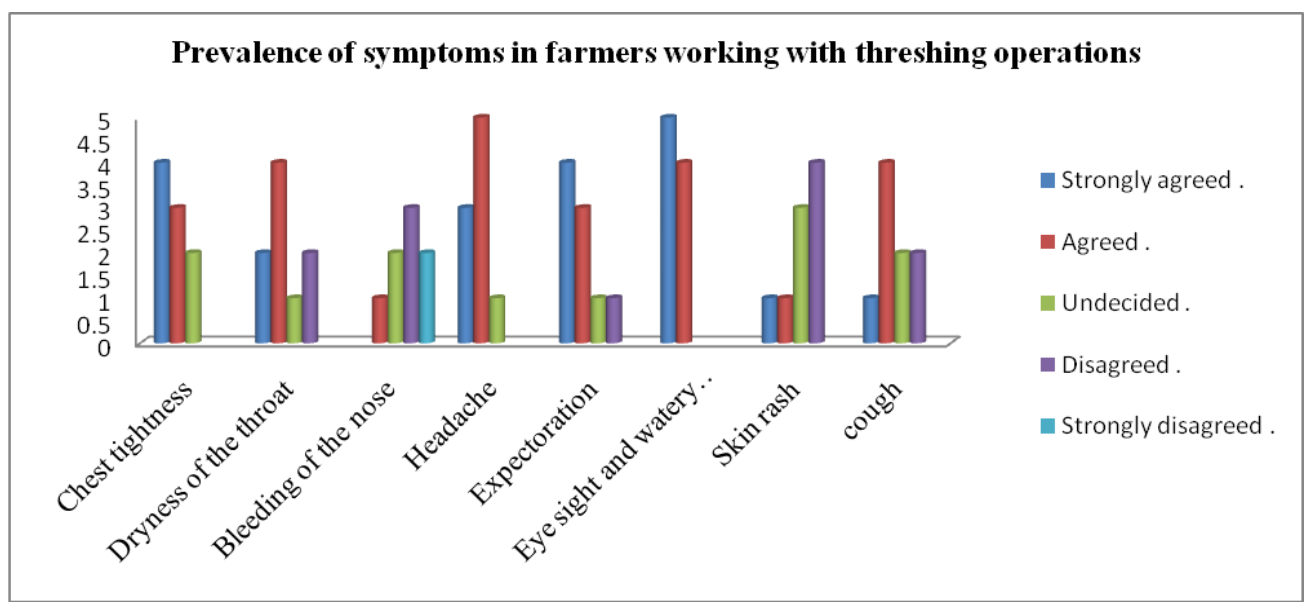


Fig.10 Suitability scores for Aesthetic dust masks prepared by muslin cloth

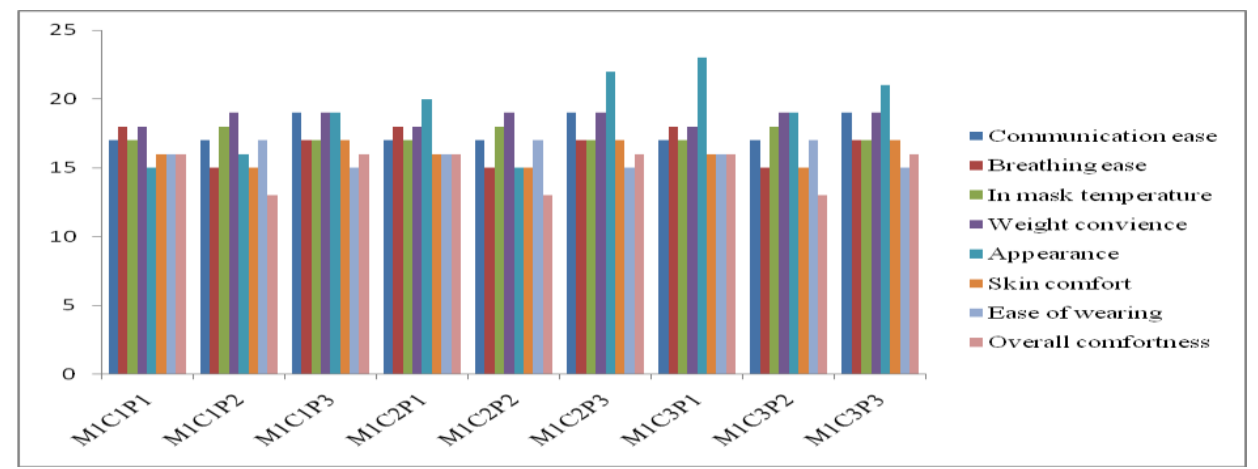

\section{Environmental parameters}

\section{Temperature $\&$ pressure}

In open field conditions under the bright sunshine the readings of ambient temperature and pressure during the threshing operation of soya bean crop were measured with palas dust monitor. The observations of ambient temperature were in the range of $22^{\circ} \mathrm{C}$ to $28^{\circ} \mathrm{C}$. and pressure changes are almost constant ranging from 951 to $955 \mathrm{pa}$ only. The experiment is carried at start of winter season in the November hence temperatures are in acceptable range for farm work is being observed.

\section{Relative humidity}

The observed relative humidity recorded by the palas dust monitor ranges from 26to 38 percent and an average relative humidity of 33 percent was observed during the entire threshing operation of soya bean crop.

Subjective assessment of dust exposure level in threshing operation \& health hazards faced by farmers

Each and every farmers working at threshing operation is investigated by an interviewer with questionnaire designed to find symptoms and health problems faced by farmers due to work environment in threshing operations.
A total of 9 male agricultural farmers and threshing labours having Work experience of 4 years in threshing were selected for detailed study. Provided the features of study population classified by level of dust exposure in Table 2.

The mean age of the selected farmers was 38 years ranging from 24 to 62 years. Among the selected farmers non smokers constitute $62 \%$, current smokers constitute $25 \%$ and ex smokers constitute $13 \%$. To obtain more accurate data subjects having farming alone as main source of income are selected for the experiment.

\section{Assessment of Symptoms \& health hazards faced by farmers due to threshing operation}

It was observed that a $44 \%$ of farmers agreed and $11 \%$ of farmers strongly agreed that they are having symptoms of cough due to dust in threshing operations while $22 \%$ of farmers undecided and $11 \%$ of farmers strongly disagreed symptoms of cough.

\section{Dust concentration level at threshing operation}

The concentration of dust was measured at different locations (near, $2.5 \mathrm{~m}, 5.0 \mathrm{~m}$, and $7.5 \mathrm{~m}$ respectively from thresher) during the threshing operation in day hours. For 
accuracy the dust concentration at different distances are taken twice perpendicular to each other.

\section{Suitability score for Aesthetic dust masks prepared by mercerized cloth}

Farmers felt low to medium communication ease and breathing ease for Aesthetic dust masks prepared by mercerized cloth. Almost all farmers felt medium to high for the in mask temperature and medium to high for weight convenience of dust mask.

In case of appearance farmers felt low for white colour and high for blue colour mask and given medium preference for yellow colour. As per the total score towel type mask made with muslin aesthetic filter material scored good and suited best for farmers.

\section{Acknowledgement}

The authors would like to thank Department of Farm machinery and Power Engineering, College of Technology and Engineering, M.P.U.A.T., Udaipur, Rajasthan, India for providing all kinds of required facilities to carry out the present study. It is my proud privilege to express my devote gratitude and indebtedness to my erudite mentor Dr.G.S. Tiwari, Professor, department of Farm Machinery and Power Engineering, C.T.A.E., Udaipur for his thoughtful guidance, constant fomenting and impeccable advices throughout the course of present study, which inspired me to carry out the research work in time.

\section{References}

Uddin, Naim, and Roma Chakraverty. (1994) "Airborne fungal load in agricultural environment during threshing operations." Mycopathologia 127.3: 145-149.

Singh, S. K., et al., (1988) "Some observations of pulmonary function tests in rice mill workers." Ind J Physiol Pharmacol 32.2: 152-7.

Simpson, J. C. G., et al., (1999) "Comparative personal exposures to organic dust and endotoxin." Annals of Occupational Hygiene 43.2: 107-115.

Schenker, Marc. (2000) "Exposures and health effects from inorganic agricultural dusts." Environmental health perspectives 108. suppl 4: 661664.

Molocznik, Anna. (2002) "Qualitative and quantitative analysis of agricultural dust in working environment." Annals of agricultural and environmental medicine 9.1:71-78.

Lee, Kiyoung, et al., (2004) "Personal exposures to inorganic and organic dust in manual harvest of California citrus and table grapes." Journal of occupational and environmental hygiene 1.8: 505-514.

Zhuang, Ziqing, and Bruce Bradtmiller. (2005) "Head-and-face anthropometric survey of US respirator users." Journal of occupational and environmental hygiene 2.11: 567-576.

Kakouei, H., and ORYAD H. MARI. (2005) "Exposure to inhalable flour dust an respirator symptom of workers in a flour mill in Iran." 50-55.

Smit, L. A. M., et al., (2006) "Agricultural seed dust as a potential cause of organic dust toxic syndrome." Occupational and environmental medicine 63.1 59-67.

Ahmed, A. H., I. E. Bilal, and T. H. Merghani.(2009) "Effects of exposure to flour dust on respiratory symptoms and lung function of bakery workers: a casecontrol study." Sudanese Journal of public health 4.1: $\mathrm{m} 210-213$.

Gandhi, Sudesh, et al., (2012) "Occupational Health Hazards \& Efficacy of Protective Masks in Threshing Operation." Work 41.Supplement 1 4983-4986. 
Singh, Narjeet. (2013). Evaluation of respirable dust filtering materials for agricultural field operations. Unpublished M.Tech Thesis, Punjab Agricultural University, Ludhiana.

Flaherty, Ann Elizabeth Randol. (2014) "Decorative cover for a respirator mask." U.S. Patent No. 8,783,253.

Patrick, Stuart. "Washable dust mask." U.S. Patent Application No. 10/154,618.

Telloli, Chiara, et al.(2014) "Properties of agricultural aerosol released during wheat harvest threshing, plowing and sowing." Journal of Environmental Sciences 26.9, 1903-1912.

Pardeshi, G. T. (2016) "Effect of Threshing on Air Pollution of In Door
Environment." Advances in Pharmacology and Toxicology 17.2; 51.

Padma, A., and Khateeja Sulthana Shaik. (2017). "Indigenous method to combat Environmental health hazards of agricultural workers while harvesting."

Yadav, Saroj. (2018) "Creating awareness among farm workers regarding health risks and use of protective clothing during harvesting and threshing activities." Indian Journal of Health \& Wellbeing 9.3

Saurabh Kumar Sahu. (2019). Intervention for minimizing threshing dust pollution.. Unpublished M.Tech Thesis, Indira Gandhi Krishi Vishwavidyalaya, Raipur

\section{How to cite this article:}

Jayakrishna, S., S. S. Meena and Tiwari, G. S. 2020. Development of an Aesthetic Agricultural Dust Mask. Int.J.Curr.Microbiol.App.Sci. 9(12): 2430-2445.

doi: https://doi.org/10.20546/ijcmas.2020.912.288 